\title{
DIALÉTICA DOS DIREITOS HUMANOS: \\ DA MODERNIDADE À PÓS-MODERNIDADE
}

\section{Caio Jesus Granduque José}

Acadêmico do $4^{\circ}$ ano do curso de Direito da Universidade Estadual Paulista/ UNESP - Franca; membro do Núcleo de Estudos de Direito Alternativo da Unesp/ NEDA e estagiário do Ministério Público do Estado de São Paulo.

e-mail: caiogranduque@yahoo.com.br

RESUMO: $O$ trabalho discute as relações dialéticas entre as três gerações de direitos humanos na modernidade $\left(1 .^{a}\right.$ geração $\times 2 .^{a}$ geração $\Rightarrow 3 .^{a}$ geração) $\mathrm{e}$, numa perspectiva prospectiva, entre esses direitos e novos direitos da natureza na pós-modernidade (direitos humanos na modernidade $X$ direitos humanos na pósmodernidade), à luz do paradigma da pós-modernidade de oposição, desenvolvido por Boaventura de Sousa Santos, com vistas à efetivação dos direitos humanos e objetivando a emancipação dos seres humanos e da natureza. A promessa moderna de emancipação do homem - enfocada na razão iluminista e na crença exacerbada na ciência - não foi cumprida, na medida em que as instituições modernas contaminaram-se pelo sistema capitalista de produção, enquanto a promessa de dominação da natureza foi muito bem realizada, de modo que nos encontramos numa crise ecológica e num estado de exclusão de milhões de pessoas, principalmente daquelas habitantes dos países periféricos ou do Sul. Em busca de superar essa situação, propugna-se - com base na democracia eco-socialista e à luz de uma ética da alteridade - pelo reconhecimento de direitos da natureza (novos direitos humanos) na pós-modernidade, já que a mais-valia econômica, que se constitui numa das faces da exploração e dominação das pessoas, está intrinsecamente ligada à exploração da natureza. Dessa forma, defende-se a criação de direitos subjetivos da natureza, intentando-se construir uma ordem jurídica, social e natural justa.

PALAVRAS-CHAVE: Dialética; Direitos humanos; Modernidade; Pós-modernidade; Razão iluminista; Ciência; Capitalismo; Neoliberalismo; "Mercadocentrismo"; Dominação; Democracia eco-socialista; Ética da alteridade; Emancipação; Filosofia da libertação; Direitos subjetivos da natureza. 
"Não há verdadeiro estabelecimento dos Direitos Humanos, sem o fim da exploração; não há fim verdadeiro da exploração, sem o estabelecimento dos Direitos Humanos"

Ernst Bloch

\section{INTRODUÇÃO}

Podemos fundamentar, sob a ótica filosófica, os direitos humanos ${ }^{1}$ em três concepções: concepção idealista, concepção positivista e concepção críticomaterialista.

De acordo com a concepção idealista, enraizada no jusnaturalismo, os direitos humanos seriam direitos supra-estatais, de caráter absoluto, imutável e universal, revelados por Deus ou inerentes ao homem, oriundos de sua própria razão.

Já a concepção positivista, advinda do positivismo jurídico, concebe os direitos humanos como aqueles que resultam da produção legislativa estatal, ou seja, devem ser observados porque se encontram na "letra da lei", fazem parte do ordenamento jurídico, como por exemplo os direitos positivados na Declaração dos Direitos do Homem de 1948, no Pacto de São José da Costa Rica ou mesmo na Constituição da República de 1988.

Por fim, a concepção crítico-materialista, inspirada na obra de Karl Marx, afirma serem os direitos humanos produtos da história, conquistados pelas lutas sociais em seu decorrer, com uma ideologia inerente de acordo com as lutas que os inspiraram.

Dessa terceira concepção é que mais nos aproximamos quando pretendemos discorrer, neste trabalho, sobre o caráter dialético de que se revestem os direitos humanos ao longo de sua história, de maneira que adotamos a dialética para esta análise seguindo o jurista Marques Neto, já que para ele:

...a dialética (...) é essencialmente aberta à crítica e à autocrítica, jamais afirmando como definitiva qualquer posição. É por sua característica intrinsecamente crítica e, portanto, 
dinâmica e renovável, que consideramos os princípios dialéticos como os mais eficazes para um estudo científico do Direito, como, de resto, dos demais ramos do conhecimento" (2001, p.180, grifos do autor).

Entretanto, deve-se ressaltar que não há uma conceituação homogênea do que seria a dialética ou mesmo o método dialético. Isso porque a dialética nasce na Grécia antiga e desenvolve-se até os dias atuais, passando de Zénon e Heráclito a Hegel e Marx.

Adota-se neste trabalho a dialética no sentido de uma forma de pensar/intervir $(n)$ a realidade de acordo com o caráter contraditório da mesma, com suas sínteses e superações que serão novamente negadas, de maneira que se percebam as transformações e a dinamicidade do movimento em devir histórico.

Com efeito, almeja-se discutir a mutabilidade e as contradições inerentes aos direitos humanos, já que estes são produtos de lutas históricas, acompanhando, pois, a dialética histórico-social, ou seja, os direitos humanos não são, mas estão sendo. Como já bem afirmou Herkenhoff, "os direitos humanos continuaram e continuam sendo construídos, na dialética da história" (apud SOUTO, 1997, p.125). No mesmo sentido, Silva: “...cada passo na etapa da evolução da Humanidade importa na conquista de novos direitos" (2003, p.149). Indicativo disso é a "...a diferença entre as declarações dos Direitos Humanos e estes mesmos Direitos", conforme nos ensinou Lyra Filho (1995, p.79).

Vale dizer, pretende-se analisar a relação dialética que se estabelece entre as três gerações ${ }^{2}$ de direitos humanos $\left(1^{a}\right.$ geração $X 2^{a}$ geração $\Rightarrow 3^{a}$ geração) dentro da modernidade, bem como a relação entre esses direitos e a proposta de novos no âmbito da pós-modernidade (direitos humanos na modernidade $X$ direitos humanos na pós-modernidade).

\footnotetext{
${ }^{1}$ Esses direitos são também denominados direitos fundamentais, direitos naturais, direitos do homem, direitos individuais, direitos públicos subjetivos, liberdades fundamentais, liberdades públicas e direitos fundamentais do homem. Em virtude dessa pluralidade de nomes para designar tais direitos, adota-se a locução "direitos humanos", pois a mesma traduz um caráter de historicidade, refletindo o processo histórico do qual emergiram esses direitos, bem como possui explícito, na palavra "humanos", o princípio da dignidade da pessoa humana.
} 


\section{Os direitos humanos na modernidade: as três gerações}

Já disse Berman: "Ser moderno é encontrar-se em um ambiente que promete aventura, poder, alegria, crescimento, autotransformação e transformação das coisas em redor - mas ao mesmo tempo ameaça destruir tudo o que temos, tudo o que sabemos, tudo o que somos" (1986, p.15).

Essas palavras traduzem bem o que é a modernidade, mormente após o advento do capitalismo. De acordo com o sociólogo português Santos: "O projeto sócio-cultural da modernidade é um projeto muito rico, capaz de infinitas possibilidades e, como tal, muito complexo e sujeito a desenvolvimentos contraditórios" (1997, p.77). Ele sustenta-se em dois pilares basilares, quais sejam: o pilar da regulação (com os princípios do Estado, mercado e comunidade) e o pilar da emancipação (com as racionalidades estético-expressivas da arte e da literatura, moral-prática da ética e do direito, bem como cognitivo-instrumental da ciência e da técnica) (cf. SANTOS, 1997, p.77).

Com efeito, o projeto da modernidade prometia incluir e emancipar todos, fazendo-se relevante destacar, com o fim de desenvolvimento de nossa temática posteriormente, que dentro dessa proposta de emancipação figuravam no campo filosófico a razão iluminista e no campo científico uma ciência tecnicista e especialista que permitia ao homem grande conhecimento e domínio da natureza.

Há que se destacar que foram adeptos dessas idéias os autores liberais burgueses e o próprio Karl Marx, o qual, apesar de ter sido a antítese desses autores, construiu sua crítica dentro da modernidade. Vale dizer: "Marx demonstrou uma fé incondicional na ciência moderna e no progresso e racionalidade que ela podia gerar" (SANTOS, 1997, p.35).

É nesse contexto que se dá a gênese das três gerações de direitos humanos, ou seja, como produto da modernidade e de suas contradições e,

2 Utiliza-se a denominação "gerações" de direitos humanos, ciente da existência da expressão "dimensões" de direitos humanos, devido ao caráter histórico e dinâmico que a denominação "gerações" passa, não se esquecendo de que tais gerações não substituem umas às outras, mas se complementam. Trabalhar-seá com três gerações de direitos humanos, não se esquecendo da proposta de autores como Paulo Bonavides, que já identificam uma quarta geração, e T. H. Marshall, N. Bobbio. I. Sarlet, J. A. de Oliverira Júnior e A. C. Wolkmer, os quais defendem cinco gerações de direitos humanos. Cf. A. Carlos WOLKMER, Novos pressupostos para a temática dos direitos humanos, p.4-5. 
conseqüentemente, em convergência com o princípio do antropocentrismo, segundo o qual o homem é o centro do Cosmos.

\section{Direitos individuais: direitos humanos de primeira geração}

A primeira geração dos direitos humanos emergiu entre os séculos $X V I$ e XVIII, com o advento da Idade Moderna, na transição do sistema de produção feudal para o capitalista.

Dessa forma, deduz-se que esses direitos nasceram das lutas burguesas contra o Antigo Regime, ou seja, nas lutas contra os privilégios da nobreza.

Contribuíram com essa luta, ou melhor, fundamentaram filosoficamente esses direitos as teorias contratualistas e os princípios liberais, inseridos no lluminismo, trabalhados e desenvolvidos, principalmente, por Locke e Rousseau.

Percebe-se, portanto, que esses direitos eram "...vistos como direitos inerentes ao indivíduo e tidos como direitos naturais" (LAFER, 1988, p.126), já que foram elaborados de acordo com o jusnaturalismo moderno.

E quais seriam esses direitos? Pode-se dizer que os direitos humanos de primeira geração materializam-se em direitos civis e políticos, cuja essência configura-se no princípio da liberdade.

Entretanto, essa liberdade restringia-se, e restringe-se, ao plano formal, pois se encontrava, e se encontra, prevista nas declarações de direitos, mas não podia, e não pode, ser exercida por todos. Para Locke, por exemplo, “...a verdadeira liberdade decorreria do exercício do direito à propriedade" (DORNELLES, 1989, p.19), e bem sabemos que nem todos possuíam (e não possuem) propriedade...

De modo que se pode dizer que os direitos de liberdade foram essenciais para que se consolidasse o modo de produção capitalista, satisfazendo os interesses burgueses, já que configuravam entre esses direitos: "livre iniciativa econômica; livre manifestação da vontade; livre cambismo; liberdade de pensamento e expressão; liberdade de ir e vir; liberdade política; mão-de-obra livre" (DORNELLES, 1989, p.21).

Portanto, "os direitos humanos, em seu primeiro momento moderno, (...) são a expressão das lutas da burguesia revolucionária com base na filosofia iluminista e na tradição doutrinária liberal" (DORNELLES, 1989, p.21), sendo, pois, considerados 
direitos naturais e vistos como intrínsecos ao indivíduo, requerendo a abstenção do Estado para o seu integral exercício.

\section{Direitos coletivos: direitos humanos de segunda geração}

Com a afirmação da burguesia como classe hegemônica na Europa e a transformação de sua condição de classe revolucionária a reacionária, com uma notável estabilidade frente ao Estado liberal, tornam-se propícias as condições para o advento da Revolução Industrial.

Essa transformação no processo produtivo fez com que se formasse uma nova classe social, qual seja, o proletariado (trabalhadores operários que não detinham os meios de produção), que passa a lutar por direitos, já que não desfrutava - e não possuía meios para tal - dos direitos de primeira geração.

Com efeito, a liberdade e igualdade propaladas nas declarações de direitos do século XVIII atinham-se - para essa nova classe - apenas ao plano formal, não passando de direitos escritos numa folha de papel, considerando-se que "...o liberalismo formula suas proposições fundamentado no binômio liberdade contratual / igualdade jurídico-formal" (MARQUES NETO, 2004, p.111).

O direito de liberdade não passava da "representação do livre exercício das atividades econômicas sem as limitações impostas à produção e à circulação das mercadorias" (DORNELLES, 1989, p.25).

De fato, de que adianta o direito à vida se não se está assegurado o direito à saúde? De que adianta o direito de ir e vir se as pessoas não têm para onde ir ou vir, ou seja, se não se tem o direito à moradia? De que adianta o direito de liberdade de expressão se não se garante o direito à educação e cultura?

Em contrapartida a essa situação e denunciando a mesma, reage o proletariado mediante o movimento sindical, com fundamento no pensamento socialista - mormente na produção teórica de Karl Marx -, reivindicando novos direitos, os quais resultarão na segunda geração dos direitos humanos.

A segunda geração dos direitos humanos materializa-se nos denominados direitos sociais, econômicos e culturais, fundados no princípio da igualdade real. Entre esses direitos estão o direito à saúde, à moradia, à educação, direito de acesso à cultura, direito ao trabalho, à previdência social etc. 
Como bem afirmou o jurista Dallari:

Diz a Constituição que todos são iguais perante a lei. É claro que isso não assegura igualdade de fato, pois na realidade essa afirmação constitucional não impede que alguns nasçam muito ricos e outros muito pobres, que uns tenham garantidas, desde o nascimento, todas as possibilidades de desenvolvimento material, intelectual e espiritual ao contrário de outros que nascem condenados a uma vida miserável. (1986, p.34).

Diferentemente dos direitos de primeira geração, estes direitos exigem a atuação do Estado, com o fim de que este crie as condições necessárias - sendo estas garantidas coletivamente - para seu exercício.

Portanto, os direitos humanos em seu segundo momento moderno são manifestações advindas das lutas proletárias nos séculos XIX e XX, com fundamentação teórica socialista, com vistas a atingir uma igualdade real, material ou substancial, sendo, para tanto, necessário o provimento estatal.

\section{Direitos dos povos: direitos humanos de terceira geração}

A terceira geração dos direitos humanos nasce no século $X X$, após a Segunda Guerra Mundial, num contexto em que figurou a experiência de Estados Totalitários, a tensão gerada pela Guerra Fria e a ampliação da utilização dos recursos naturais.

Nesse contexto, os direitos nascem das lutas dos novos movimentos sociais, com um caráter - diferentemente dos dois períodos anteriores - supraclassista, sendo de titularidade dos povos, vale dizer, são direitos globais.

Entre esses novos direitos, destacam-se o direito à paz, ao desenvolvimento, à autodeterminação dos povos, a um meio ambiente saudável e ecologicamente equilibrado e à utilização do patrimônio comum da humanidade (cf. DORNELLES, 1989, p.35-36).

O valor que fundamentalmente caracteriza esses direitos é o da solidariedade, pois são direitos que interessam à humanidade como um todo, resgatando valores humanísticos mínimos, com o fim de que o mundo não seja destruído por completo.

Dessa forma, para a promoção desses direitos faz-se necessário o esforço não só do Estado, mas também dos indivíduos, de modo que atuem conjuntamente. 
Portanto, os direitos humanos em seu terceiro momento moderno surgem das lutas dos novos movimentos sociais, com base no princípio da solidariedade, necessitando para sua garantia a participação conjunta de indivíduos e Estado.

\section{A dialética das gerações: $1^{\mathrm{a}}$ geração $\times 2^{\mathrm{a}}$ geração $\Rightarrow 3^{\mathrm{a}}$ geração}

A contradição é reconhecida pela dialética como princípio básico do movimento pelo qual os seres existem (cf. KONDER, 1994, p.48-49). "Cada fato, pois, em qualquer esfera do mundo, constitui uma unidade de contrários" (LLANOS, 1988, p.209).

Isso se torna mais facilmente perceptível no diálogo entre Deus e o Diabo na obra O Evangelho segundo Jesus Cristo do escritor português José Saramago. Diz Deus ao Diabo: “...este Bem que eu sou não existiria sem esse Mal que tu és, um Bem que tivesse de existir sem ti seria inconcebível, (...) enfim, se tu acabas, eu acabo" (1991, p.392-393).

Entretanto, “...os contrários não podem manter entre si uma relação pacífica e indiferente. Os contrários lutam uns contra os outros e por esse meio resolvem suas contradições” (LLANOS, 1988, p.209) num movimento contínuo.

Desse modo, pode-se resumir o princípio dialético da contradição na analogia de uma tese que será contraposta por uma antítese, fato que resultará numa síntese, a qual extrai as diferenças entre elas, sendo contraposta por uma anti-síntese, resultando numa segunda síntese, que conserva dentro de si a antítese e a tese da anterior, não se perdendo nada à medida que a dialética avança (Tese $X$ Antítese $\Rightarrow$ Síntese X Anti-síntese $\Rightarrow$ Síntese2...) (cf. LLANOS, 1988, p.100).

Ousaríamos dizer que os direitos humanos, em sua gênese, identificam-se com esse processo, já que se configuram em produto das lutas históricas, as quais seguem o movimento dialético.

Como já bem nos ensinou Dornelles:

cada geração de direitos humanos nasceu e se desenvolveu representando momentos históricos onde os indivíduos, os oprimidos, os explorados, os injustiçados, os expropriados levantaram a bandeira da libertação e emancipação humana, conquistando duramente espaços democráticos e liberdades possíveis no contexto histórico (1989, p.67). 
Assim, a primeira geração dos direitos humanos, que resultou das lutas burguesas contra o Antigo Regime e fundou-se em direitos de liberdade a serem exercidos individualmente com a abstenção estatal, foi contraposta pela segunda geração dos direitos humanos, que resultou das lutas proletárias e fundou-se em direitos de igualdade a serem exercidos coletivamente pela atuação estatal.

Fazendo eco com Santos: “...a modernidade ocidental desdobrou-se em duas concepções e práticas de direitos humanos profundamente divergentes - a liberal e a marxista - uma dando prioridade aos direitos cívicos e políticos [primeira geração], a outra dando prioridade aos direitos sociais e econômicos [segunda geração]" (2002, p.7).

Dessa contradição dialética entre as duas gerações produziu-se uma síntese, materializada na terceira geração dos direitos humanos, que resultou das lutas dos novos movimentos sociais de caráter supraclassista e fundou-se em direitos de solidariedade a serem exercidos globalmente pela atuação dos indivíduos e do Estado. De fato, "os direitos dos povos [terceira geração] são ao mesmo tempo 'direitos individuais' e 'direitos coletivos', e interessam a toda humanidade" (DORNELLES, 1989, p.33). São direitos que resultaram da luta conjunta de burgueses e proletários, fundados no valor da solidariedade, o qual comporta os outros dois valores.

A liberdade garantida de modo estanque gera graves desigualdades, como também a igualdade garantida sozinha suprime a liberdade, sendo a solidariedade um valor que concilia esses outros dois, estando expressa nas seguintes palavras: "...as pessoas e os grupos sociais têm o direito a ser iguais quando a diferença os inferioriza, e o direito a ser diferentes quando a igualdade os descaracteriza" (SANTOS, 2002, p.12).

\section{OS DIREITOS HUMANOS NA PÓS-MODERNIDADE: A INSURGÊNCIA DE DIREITOS DA NATUREZA}

As promessas da modernidade de inclusão e emancipação de todos não foram e não podem ser cumpridas em seu âmbito. Como diz Santos: "...depois de dois séculos de promiscuidade entre modernidade e capitalismo tais promessas, 
muitas delas emancipatórias, não podem ser cumpridas em termos modernos nem segundo os mecanismos desenhados pela modernidade" (1997, p.35).

No plano filosófico, a razão iluminista, que se pretendia humanística e emancipatória, transforma-se na razão instrumental, “...dominação calculada e calculável (...) exercida sobre os homens e a natureza" (FREITAG, 1990, p.91), e no plano científico, "a ciência unidimensionalizada é utilizada para dominar a natureza, e com isso acelerar a produção, (...) e os homens, já que eles se subordinam cada vez mais ao processo produtivo" (FREITAG, 1990, p.93). ${ }^{3}$

Bem resume essa situação os frankfurtianos Adorno e Horkheimer: "O indivíduo se vê completamente anulado em face dos poderes econômicos. Ao mesmo tempo, estes elevam o poder da sociedade sobre a natureza a um nível jamais imaginado" (1985, p.14). De modo que "o que os homens querem aprender da natureza é como empregá-la para dominar completamente a ela e aos homens" (1985, p.20). Há que se ressaltar ter sido a empresa a instituição moderna que melhor concretizou essa exploração do homem e da natureza.

Nesse contexto, as promessas referentes à concretização e respeito dos direitos humanos também não se consumaram. A realidade mostra que milhões de pessoas não desfrutam do mínimo direito à vida, morrendo de fome, por falta de básicas condições de saúde, ou mesmo pelos "esquadrões da morte". Crianças prostituem-se e trabalham, tendo sua infância e dignidade arrancadas pelo ideário neoliberal de supervalorização do mercado. ${ }^{4} \mathrm{O}$ desemprego é avassalador, massacres e linchamentos são freqüentes, guerras e intervenções militares são constantes, enfim, o ser humano torna-se supérfluo e descartável.

Recorrendo novamente ao sociólogo português, pode-se dizer que:

\footnotetext{
${ }^{3}$ Kurs faz um diagnóstico pessimista: "Ao atingirem o capitalismo científico e a ciência capitalista certas fronteiras naturais e ao tentarem rompê-las à força, sua lógica reducionista e mecanicista ameaça transformarse, para além da insidiosa destruição dos fundamentos naturais da vida, na criação de tecnologias francamente apocalípticas de autodestruição" (2004, p.235). "O complexo econômico-científico, com auxílio da tecnologia genética, quer produzir à sua imagem plantas, animais e, em última instância, pessoas que, mesmo no plano biológico elementar, sejam segunda natureza e, portanto, criaturas do capital, cuspidas e escarradas" (2004, p.237, grifo do autor). E mais adiante adverte: "Se o conhecimento científico não se emancipar da lógica de uma objetivação desumana da natureza, o complexo econômico-científico logrará transformar a Terra num deserto da física” (2004, p.238). Morin afirma nessa esteira: “... a dominação desenfreada da natureza pela técnica conduz a humanidade ao suicídio" (2000, p.71).

${ }^{4}$ Traduz bem esse ideário as palavras do ex-presidente George Bush, em setembro de 1992: "o tempo de caridade acabou!" (cf. MARQUES NETO, 2004, p.113).
} 
No que respeita à promessa de igualdade, os países capitalistas avançados com $21 \%$ da população mundial controlam $78 \%$ da produção mundial de bens e serviços e consomem $75 \%$ de toda a energia produzida. Mais pessoas morrem de fome no século [século XX] que em qualquer dos séculos precedentes.

No que respeita à promessa da liberdade, as violações dos direitos humanos em países vivendo formalmente em paz e democracia assumem proporções avassaladoras. (2000, p.23-24)

Cinicamente, o princípio moderno do antropocentrismo, vinculado à própria insurgência dos direitos humanos, deu lugar ao mercadocentrismo. ${ }^{5}$ Com efeito, "....apesar da importância concedida pelos autores neoliberais aos direitos humanos, o sujeito não está mais no centro do universo jurídico. Ele é substituído, nesse centro, pela lei do mercado" (ARNAUD, 1999, p.232). De modo que se pode dizer que os sujeitos de direitos têm espaço cada vez menor frente aos sujeitos de dinheiro. ${ }^{6}$

Em contrapartida às promessas não cumpridas, algumas foram cumpridas em excesso. Nas palavras de Boaventura: “....a promessa da dominação da natureza foi cumprida de modo perverso sob a forma de destruição da natureza e da crise ecológica (...). Nos últimos 50 anos o mundo perdeu cerca de um terço de sua cobertura florestal. Um quinto da humanidade já não tem hoje acesso a água potável" (SANTOS, 2000, p.24).

Nesse ponto, Marx, com sua crítica inserida na modernidade, falha, pois "...não viu (...) a articulação entre a exploração do trabalho e a destruição da natureza e, portanto, a articulação entre as contradições que produzem uma e outra" (SANTOS, 1997, p.44).

Desse modo, parece claro que passamos por um momento de crise, no sentido gramsciano do termo, em que o paradigma da modernidade morreu e não responde mais aos seus anseios, e um novo paradigma ainda não está pronto para

5 "O Mercado, esse ser metafísico, inatingível e indestrutível enquanto tal, é o verdadeiro soberano no mundo da economia globalizada. Destituído do lugar de soberania para o de simples garantidor do livre funcionamento do mercado, ou seja, da competição, o Estado contemporâneo vai sofrendo sua afânise: apequena-se, minimiza-se" (MARQUES NETO, 2004, p.109).

6 "Cidadão, no mundo neoliberal, nada mais é do que aquele que pode consumir" (MARQUES NETO, 2004, p.109). 
nascer. Pode-se chamar esse novo paradigma de pós-modernidade, por não haver um nome mais adequado para designá-lo (cf. SANTOS, 1997, p.34). ${ }^{7}$

Nessa fase de transição paradigmática, pode-se dizer que insurge 0 paradigma da democracia eco-socialista como antítese ao paradigma da democracia autoritária de capital-expansionista atual (cf. SANTOS, 1997, p.342-343).

Esse paradigma insurgente visa suprimir toda espécie de mais-valia existente, já que "a mais-valia pode ser sexual, étnica, religiosa, etária, política, cultural; (...) pode ainda ter lugar nas relações sociais de destruição entre a sociedade e a natureza, ou melhor, entre os recursos ditos "humanos" e os recursos ditos "naturais" da sociedade" (SANTOS, 1997, p.260).

De modo que acreditamos que os direitos humanos gerados na modernidade só serão efetivados no âmbito desse novo paradigma, com a geração de novos direitos que acompanhem a dialética histórico-social e estabeleçam uma nova relação com a natureza.

Isto é, para se pôr fim às várias "mais-valias" ou formas de exploração, sobretudo à mais-valia econômica - ou seja, a mais-valia no sentido marxista do termo - faz-se fundamental o respeito à natureza. ${ }^{8}$ Deve-se, pois, criar um novo senso comum, no qual o princípio do mercadocentrismo, dissimulado no antropocentrismo, seja abolido, de modo a se resgatar a dignidade da pessoa

${ }^{7}$ Ciente da polêmica que a locução "pós-modernidade" causa, com acusações e defesas de diversos autores, optamos pelo "pós-modernismo de oposição" - consoante proposta de Boaventura de Sousa Santos de forma a lutar pela efetivação de algumas promessas da modernidade, tais como a promessa de emancipação humana, não se esquecendo de que o Brasil é um país de modernidade tardia, no qual há um amálgama de bolsões pré-modernos, modernos e pós-modernos. Sobre esse debate, consultar: HARVEY, David. Condição pós-moderna. 4.ed. São Paulo: Loyola, 1994; EAGLETON, Terry. As ilusões do pós-modernismo. Rio de Janeiro: Jorge Zahar, 1998; ANDERSON, Perry. As origens da pós-modernidade. Rio de Janeiro: Jorge Zahar, 1999; GUERRA FILHO, Willis Santiago. Autopoiese do Direito na Sociedade pós-moderna: introdução a uma teoria social sistêmica. Porto Alegre: Livraria do Advogado, 1997; BAUMAN, Zygmunt. Modernidade Líquida. Rio de Janeiro: Jorge Zahar, 2000; ARRUDA JUNIOR, Edmundo Lima. O moderno e o pós-moderno no direito. In: Sociologia e Direito. Cláudio Souto; Joaquim Falcão. São Paulo: Pioneira, 1999; COELHO, Luiz Fernando. $A$ teoria crítica do direito na pós-modernidade. Disponível em: http: www.ccj.ufsc.br; $O$ nascimento do hipermoderno. Folha de São Paulo, Caderno Mais!, 14/03/2004; O pós-modernismo morreu?. Folha de São Paulo, Caderno Mais!, 02/11/2003.

${ }^{8} \mathrm{O}$ que se propõe aqui não se coaduna com as propostas dos "verdes de direita", os quais defendem a natureza de forma "fundamentalista", colocando-se esta acima dos próprios seres humanos, quando estes são os "outros". Ademais, nota-se que a idéia de respeito à natureza está forte a ponto de se fabricar o carro ecosport, os cosméticos que respeitam a natureza, sem prejuízo de se ter o Banco que investe em preservação ambiental, tudo isso ao mesmo tempo em que milhões de pessoas não possuem direitos animalescos (relacionados à própria existência e sobrevivência) neste país. Vale dizer, repugnamos atitudes de socialites que alimentam seus cachorros e cadelas com comida que milhões de "outros" brasileiros nunca consumiram. O que se defende é o reconhecimento de direitos à natureza com o fim de emancipação desta e, sobretudo, do ser humano. Melhor esclarece Morin: "Devemos reconhecer nosso duplo enraizamento no cosmos físico e na esfera viva e, ao mesmo tempo, nosso desenraizamento, propriamente humano. Estamos simultaneamente dentro e fora da natureza" (2000, p.48). 
humana com a efetivação concomitante das gerações de direitos humanos (indivisibilidade e cumulatividade dos direitos humanos). ${ }^{9}$

Recorrendo novamente ao sociólogo português:

Desde o século XVI que o homem tem com a natureza uma relação estruturalmente pobre e desequilibrada, uma relação de exploração assente numa concepção unidimensional da natureza. Ao reduzir a natureza à matéria-prima sobre a qual o homem soberano inscreve o sentido histórico do processo de desenvolvimento, a ciência moderna provoca uma ruptura ontológica entre o homem e a natureza na base da qual outras se constituem (ou reconstituem), tais como a ruptura entre o sujeito e o objeto do conhecimento e, mais tarde, a ruptura entre as ciências naturais e as ciências sociais. A natureza é desumanizada e o homem, desnaturalizado, e assim se criam as condições para que este último possa exercer sobre a natureza um poder arbitrário, ética e politicamente neutro. Mas esse homem desnaturalizado não é um homem qualquer, uma entidade abstrata, ainda que seja assim que a filosofia ocidental o concebe. Em termos sociológicos esse homem é o burguês, no sentido original da palavra, é a classe revolucionária que transporta em si o espírito emergente do capitalismo e que vai utilizar a relação de exploração da natureza para produzir um desenvolvimento das forças produtivas sem precedentes na história da humanidade. Daí que a relação de exploração da natureza seja pré-condição da relação de exploração do homem pelo homem instaurada pelo modo de produção capitalista. As duas relações pertencem-se naturalmente e a ação sobre uma delas não deixará, por certo, intacta a outra. Perante os resultados destrutivos, hoje evidentes, desta relação entre o homem e a natureza, uma luta socialista paradigmática terá de ser também uma luta por uma nova concepção de natureza e por uma relação mais rica e equilibrada entre o homem e a natureza. (1990, p.70, grifo nosso)

Assim, os direitos humanos são dialeticamente contrapostos por novos direitos da natureza. O homem não é o centro do Cosmos, mas parte integrante dele. Como afirmou o teólogo Boff: "O antropocentrismo é um equívoco, pois o ser humano não é um centro exclusivo, como se todos demais seres somente

${ }^{9}$ Em relação à tensão dialética entre as gerações de direitos humanos, conforme defendido acima, propugna-se por uma "dialética da complementação" em detrimento de uma "dialética do antagonismo", conforme posição de Sarlet quando fala da relação entre os direitos de defesa ( $1^{a}$ geração) e os direitos sociais a prestações ( $2^{2^{3}}$ geração) (cf. 2003, p.71). 
ganhassem sentido enquanto ordenados a ele. Ele é um elo, entre outros, da corrente da vida" (2002, p.10). ${ }^{10}$

Já bem disse o jurista Trindade: "Embora os domínios da proteção do ser humano e da proteção ambiental tenham sido tratados até o presente separadamente, é necessário buscar maior aproximação entre eles, porquanto correspondem aos principais desafios de nosso tempo, a afetarem (...) os rumos e destinos do gênero humano" (1993, p.23).

E por que não foram assegurados ainda direitos à natureza? Porque "a concepção ocidental dos direitos humanos (...) apenas garante direitos àqueles a quem pode exigir deveres", de acordo com a ética liberal, deduzindo-se, pois, que “...a natureza não possui direitos porque não the podem ser impostos deveres" (SANTOS, 2002, p.9).

Fazendo eco com Boff, é importante destacar que:

Bem disse o pensador Michel Sevres: "A Declaração dos Direitos do Homem teve o mérito de dizer 'todos os homens têm direitos' e o defeito de pensar 'só nos homens'." Os indígenas, os escravos e as mulheres tiveram de lutar para serem incluídos em "todos os homens". E hoje essa luta inclui a inteira natureza com seus subsistemas, também sujeitos de direitos e, por isso, novos membros da sociedade ampliada. (2002, p.10)

Nesse sentido, Santos chega a propor a criação de uma "Carta dos direitos humanos da natureza" (cf. 1997, p.44), afirmando ainda que "a politização da natureza envolve a extensão a esta do conceito de cidadania, o que significa uma transformação radical da ética política da responsabilidade liberal, assente na reciprocidade entre direitos e deveres. Será então possível atribuir direitos à natureza sem, em contrapartida, ter de lhe exigir deveres" (1997, p.274-275). Vale dizer que a nova ética seria uma ética da alteridade fundada no novo princípio da responsabilidade, ou seja, “...na preocupação ou cuidado que nos coloca no centro de tudo o que acontece e nos torna responsáveis pelo outro, seja ele um ser humano, um grupo social, a natureza, etc."(SANTOS, 2000, p.112). Neste último caso, pode-se dizer que “...a natureza, dita não-humana, não nos sendo idêntica, é-

\footnotetext{
${ }^{10}$ Há autores que chegam a defender uma dimensão psíquica da natureza. 'A 'consciência ampla' de Bateson refere-se a uma dimensão psíquica da natureza, uma consciência imanente a toda a ecologia planetária, da qual a consciência humana é apenas uma parte. Bateson afirma ainda que, enquanto Freud ampliou o conceito de mente para dentro (permitindo-nos abranger o subconsciente e o inconsciente), precisamos agora de o ampliar para fora (reconhecendo a existência de fenômenos mentais para além dos
} 
nos recíproca na medida em que, por exemplo, a sua destruição acarreta a nossa própria destruição. Assim, a nossa subjectividade não se completa sem ela" (SANTOS, 2000, p.81).

A degradação da sociedade está intrinsecamente ligada à degradação da natureza. Nas palavras de O'Connor, "que pretende desenvolver um 'marxismo ecológico' como método para teorizar os novos movimentos sociais num amplo enquadramento marxista" (apud SANTOS, 2000, p.280):

Se considerarmos que as taxas de destruição e poluição da natureza dependem da taxa de acumulação e da taxa de lucro, quaisquer aumentos da taxa de exploração do trabalho farão aumentar as taxas de lucro e, conseqüentemente, as taxas de destruição e poluição. Quanto mais o capital explorar o trabalho, mais explorará a natureza, e vice-versa. (SANTOS, 2000, p.281, grifo nosso)

Hodiernamente, tal tutela da natureza ocorre por via reflexa. Isso porque, na medida em que nosso ordenamento tutela os interesses e direitos difusos, dentre os quais o interesse e direito a um meio ambiente saudável, a natureza é tutelada. Vale dizer, quando o Judiciário tutela o direito a um meio ambiente saudável, na perspectiva da humanidade como um todo - visando ao bem-estar humano - a natureza, por via oblíqua, também é contemplada. De maneira que um largo instrumental jurídico está à disposição dos operadores para a efetivação dessa proteção. $^{11}$

A virada paradigmática aqui proposta procura aumentar esse instrumental jurídico. Nesse sentido, intenta-se trazer ao plano concreto e local os direitos difusos relativos ao meio ambiente, com vistas a uma melhor tutela. Ou seja, com a proposta de direitos da natureza, o conflito se solidifica e se torna mais claro quando são postos em pólos opostos os interesses da natureza e os econômico-individualistasempresariais, sem esquecer que muitas das vezes não se tem uma tutela efetiva dos

individuais e humanos) - Bateson (1985). Opiniões semelhantes podem se encontrar em Capra (1983 e 1984) e em Bohm (1984)" (SANTOS, 2000, p.90).

11 Exemplo disso são as normas decorrentes do art. 225 da Constituição da República, da Lei n. 6.938/1981 (Lei do Meio Ambiente), da Lei n. 9.605/1998 (Lei dos crimes contra o Meio Ambiente), da Lei n. 7.347/1985 (Lei da Ação Civil Pública) e da Lei n. 8.078/1990 (Código de Proteção e Defesa do Consumidor), formando estas duas últimas um microssistema de tutela jurisdicional coletiva geral (Cf. Gregório Assagra de ALMEIDA. Direito processual coletivo brasileiro: um novo ramo do direito processual. São Paulo: Saraiva, 2003). 
direitos difusos em virtude de estes serem tidos como res nullius e não como res omnium. $^{12}$

Para tanto, poder-se-ia vislumbrar uma nova categoria de direitos subjetivos, vale dizer, ao lado dos direitos subjetivos stricto sensu e direitos subjetivos coletivos, os direitos subjetivos da natureza, sem prejuízo da criação do conceito de interesse natural a conviver em harmonia com os interesses individual, coletivo, difuso, social e público. ${ }^{13}$ No plano processual, poder-se-ia invocar a Teoria Institucional ou Objetivista (Cf. MANCUSO, 2000, p.187) para fundamentar a representação desses direitos em juízo, sem prejuízo de se entender que a legitimidade para tanto poderia ser conferida aos legitimados para a proposição da Ação Civil Pública (art. $5^{\circ}$ da Lei n. 7.347/1985), já que gozam de "legitimação autônoma para a condução do processo", segundo a teoria de Nery Júnior e Nery (apud ALMEIDA, 2003, p.499). ${ }^{14}$

Nesse contexto, fundamental a participação do Ministério Público, já que se com a nova ordem constitucional o órgão ministerial assume o papel, segundo Souto, de custos legis, custos societatis e custos juris (cf. 1997, p.85), com esse novo paradigma o Parquet assumiria também a função de custos naturae.

Acreditamos que por esses caminhos estaremos construindo uma ordem jurídica, social e natural justa. Não há verdadeiro fim da exploração dos seres humanos sem o fim da exploração da natureza; não há fim verdadeiro da exploração da natureza sem o fim da exploração dos seres humanos.

12 Diante da possibilidade de estarmos “...perante uma 'nova' divisão global do trabalho no sistema mundial que inclui a divisão global da destruição da natureza e da poluição (altos níveis na periferia do sistema, relativamente baixo níveis no centro)" (SANTOS, 2000, p.281), acreditamos que a tutela da natureza pode se constituir em poderoso instrumento de resistência contra-hegemônica dos países periféricos - também denominados países do Sul -, numa perspectiva da filosofia da libertação, à hegemonia neoliberal, a qual se apóia em multinacionais do centro para explorar nossas populações locais e nossa natureza. Como diria Dussel, “... a natureza é politicamente interpretada: é hermeneuticamente visualizada desde o centro ou a periferia, desde as diversas classes sociais, desde os sistemas políticos (...)" (1980, p.114). Importante, nesse ínterim, o conceito de "florestania" criado no Acre para indicar uma nova relação do cidadão habitante da floresta: "convive com a floresta, como um novo cidadão, vive de sua biodiversidade, sem agredi-la ou extenuar sua riqueza" (BOFF, 2002, p.10).

${ }^{13}$ Essa proposta leva em consideração a crítica de Miranda às teorias jurídicas pré-modernas, como a de Bekker, que afirmaram poderem ser sujeitos de direitos as coisas e os animais. Disse o famoso autor: "Se o sistema jurídico, como sistema lógico, atribui direito a animais e a coisas, tais animais e coisas não são objeto, são sujeito; e exatamente em só atribuírem direitos a homens e a entidades, de que se precisava para as relações da vida, consistiu uma das linhas da evolução jurídica" (1999, p.220, grifo nosso). Nesse sentido, hoje é necessária a concessão de direitos à natureza, pois se torna fundamental para "as relações da vida", como o fora anteriormente a atribuição de direitos a entidades como as pessoas jurídicas, as quais, por ficção jurídica, são sujeitos de direito.

\footnotetext{
${ }^{14}$ Nesse sentido, Stone, em artigo intitulado "Should trees have standing? Toward legal rights for natural objects" pretende que se admitam ao universo jurídico os "natural objects", como, por exemplo, as árvores (apud MANCUSO, 2000, p. 151).
} 


\section{BIBLIOGRAFIA}

ADORNO, Theodor W.; HORKHEIMER, Max. Dialética do esclarecimento: fragmentos filosóficos. Trad. Guido A. de Almeida. Rio de Janeiro: Jorge Zahar Ed., 1985.

ALMEIDA, Gregório Assagra de. Direito processual coletivo brasileiro: um novo ramo do direito processual. São Paulo: Saraiva, 2003

ARNAUD, André-Jean. $O$ direito entre a modernidade e a globalização: lições de filosofia do direito e do Estado. Trad. Patrice C. Wuillaume. Rio de Janeiro: Renovar, 1999.

BERMAN, Marshall. Tudo que é sólido desmancha no ar: a aventura da modernidade. Trad. Carlos F. Moisés e Ana M. L. Ioriatti. São Paulo: Companhia das Letras, 1986.

BOFF, Leonardo. O ideal e o real na ecologia: a nova utopia da sociedade tem de incluir também a natureza, além das pessoas. Caros Amigos: Especial democracia. São Paulo, ano VI, n. 15, p. 10, nov. 2002.

DALLARI, Dalmo de Abreu. O que são direitos da pessoa. 9. ed. São Paulo: Brasiliense, 1986.

DORNELLES, João R. W. O que são direitos humanos. São Paulo: Brasiliense, 1989.

DUSSEL, Enrique D. Filosofia da libertação. São Paulo: Loyola, 1980.

FREITAG, Barbara. A teoria crítica: ontem e hoje. 3. ed. São Paulo: Brasiliense, 1990.

KONDER, Leandro. O que é dialética. 27. ed. São Paulo: Brasiliense, 1994.

KURZ, Robert. Natureza em ruínas. In: Com todo vapor ao colapso. Juiz de Fora: UFJF; Pazulin, 2004.

LAFER, Celso. A reconstrução dos direitos humanos: um diálogo com o pensamento de Hannah Arendt. São Paulo: Companhia das Letras, 1988.

LLANOS, Alfredo. Introdução à dialética. Trad. Cid Silveira. Rio de Janeiro: Civilização Brasileira, 1988.

LYRA FILHO, Roberto. O que é direito. 17. ed. São Paulo: Brasiliense, 1995.

MANCUSO, Rodolfo de Camargo. Interesses difusos: conceito e legitimação para agir. 5. ed. São Paulo: RT, 2000.

MARQUES NETO, Agostinho R. Neoliberalismo: o declínio do direito. In: Direitos humanos e globalização: fundamentos e possibilidades desde a teoria crítica. Rio de Janeiro: Lúmen Júris, 2004. p. 103-116.

MARQUES NETO, Agostinho R. A ciência do direito: conceito, objeto e método. 2. ed. Rio de Janeiro: Renovar, 2001.

MORIN, Edgar. Os sete saberes necessários à educação do futuro. Trad. Edgar de Assis Carvalho. São Paulo: Unesco; Cortez, 2000. 
PONTES DE MIRANDA, Francisco Cavalcanti. Tratado de direito privado. Tomo I. Campinas: Bookseller, 1999.

SANTOS, Boaventura de Sousa. A crise do paradigma. In SOUSA JÚNIOR, José Geraldo (Org). O direito achado na rua. Brasília: Editora Universidade de Brasília, 1990.

SANTOS, Boaventura de Sousa. Pela mão de Alice: o social e o político na pós-modernidade. 4. ed. São Paulo: Cortez, 1997.

SANTOS, Boaventura de Sousa. A crítica da razão indolente: contra o desperdício da experiência. São Paulo: Cortez, 2000.

SANTOS, Boaventura de Sousa. As tensões da modernidade. http://www.antroposmoderno.com/ textos/ astensoes.shtml. Acesso em: 29 ago. 2002.

SARAMAGO, José. O Evangelho segundo Jesus Cristo. São Paulo: Companhia das Letras, 1991.

SARLET, Ingo W. Os direitos fundamentais sociais na ordem constitucional brasileira. Revista do instituto de hermenêutica jurídica, Porto Alegre, v.1, n.1, p. 47 - 95, 2003.

SILVA, José Afonso da. Curso de Direito Constitucional Positivo. 22. ed. São Paulo: Malheiros, 2003.

SOUTO, Cláudio. Tempo do direito alternativo: uma fundamentação substantiva. Porto alegre: Livraria do advogado, 1997.

TRINDADE, Antônio A. Cançado. Direitos humanos e meio-ambiente: paralelo dos sistemas de proteção internacional. Porto Alegre: Sérgio Antônio Fabris, 1993.

WOLKMER, Antônio C. Novos pressupostos para a temática dos direitos humanos. In: Direitos humanos e globalização: fundamentos e possibilidades desde a teoria crítica. Rio de Janeiro: Lúmen Júris, 2004. p. 3-19. 